\title{
Cytogenetic Effects of Combined Ochratoxin A and Endosulfan in Rats
}

\section{Shashi Nandar Kumar ${ }^{1 *}$, Avinash Gopal Telang², Rajendra Damu Patil ${ }^{3}$, Arun Kumar Jain ${ }^{1}$ and Karam Pal Singh ${ }^{2}$}

${ }^{1}$ Environmental Toxicology Laboratory, National Institute of Pathology (ICMR), Safdarjung Hospital Campus, New Delhi-110 029, India

${ }^{2}$ Centre for Animal Disease Research and Diagnosis (CADRAD), Indian Veterinary Research Institute, Izatnagar, Bareilly-243 122 (UP), India

${ }^{3}$ Department of Veterinary Pathology, Dr G C Negi College of Veterinary and Animal Sciences, Himachal Pradesh Agricultural University, Palampur-176 062 (HP), India

\begin{abstract}
An attempt was made to study the genotoxic effects of Ochratoxin A (OTA) and endosulfan, alone and in combination by in vivo micronuclei (MN) and chromosomal aberration (CA) assays in bone marrow cells. OTA (4 mg/kg feed) and endosulfan ( $5 \mathrm{mg} / \mathrm{kg}$ body weight) were administered orally, alone and in combination, to male Wistar rats daily for 30 days. Significantly higher MN frequencies and decreased ratios of polychromatic to normochromatic erythrocytes (indicator of cytotoxicity), were recorded in individual or combined treatment of OTA and endosulfan as compared with the control. Chromosomal aberrations such as gaps, isochromatid gaps, breaks and fragments were recorded in the bone marrow cells. The percent frequencies of aberrant cells were significantly higher in all the treated groups as compared to the control. The severity of genotoxic effects was more in the combination treatment group, suggesting an additive or less than additive interaction of OTA and endosulfan in rats.
\end{abstract}

Keywords: Ochratoxin A; Endosulfan; Rat; Genotoxicity; Micronuclei

\section{Introduction}

Ochratoxin A (OTA) is a potent nephrotoxic mycotoxin, mainly produced by several species of fungal genera Aspergillus and Penicillium. It is a widespread natural contaminant in various food or feed commodities, resulting in toxicosis in animal and human populations. OTA possesses general structure of L- $\beta$-phenylalanine linked by an amide bond to dihydro-isocoumarin moiety. Unfavorable elimination toxico-kinetics of OTA displays an extremely high interspecies variability and has been found to exert its deleterious effects in terms of nephrotoxicity, mutagenicity, neurotoxicity, immunotoxicity, carcinogenicity, genotoxicity and teratogenicity in various mammalian species [1-3]. OTA has been suggested by various researchers to mediate its toxic effects via induction of apoptosis; disruption of mitochondrial respiration and/or the cytoskeleton or via generation of oxidative stress and DNA adducts [4-6]. OTA crosses the placenta and causes adducts in the DNA of liver and kidneys newborns [7]. OTA is strongly implicated as the cause of Balkan endemic nephropathy (BEN), a fatal tubule-interstitial disease that is associated with renal atrophy and that exhibits features similar to porcine nephropathy in Bulgaria. Approximately $30 \%$ of patients dying with BEN have tumors of the urinary tract [8].

Endosulfan, an organochlorine insecticide and acaricide acts as a contact poison in a wide variety of insects and mites [9]. It is a highly toxic, ubiquitous environmental pollutant that causes long-term harm to humans, animals, wildlife and in aquatic system [10,11]. It is further classified as moderately hazardous (Class II) chemical by World Health Organization [12] and widely considered to be a Persistent Organic Pollutant [13]. It is readily absorbed by stomach, lungs and through the skin. It is a potential environmental pollutant and has gained public health significance due to its low water solubility, chemical stability, high lipid solubility and slow rate of bio-transformation. There is bioconcentration and bio-magnification of endosulfan in food chains by its lipophilic nature [14].

In India, endosulfan residues have been reported to occur in high levels in various samples of cashew, fruits, milk, butter, coconut oil, soil, ground water and even in human blood in Kasargod district of Kerala [15]. It has also been studied experimentally for its endocrine or hormonal disrupting potential [16], testicular atrophy in male rats [17] and also reported to cause apoptosis [18], oxidative damage [19], hepatotoxicity [20] and immunotoxicity. In humans, it is also reported to cause social death [21], uterine leiomyomas, non-Hodgkin's lymphomas [22] and delayed sexual maturity due to interference with sex hormone synthesis [23].

The perused literature revealed very scanty information on the in vivo genotoxic effects of OTA and endosulfan in animals or human beings. Moreover, no report could be traced in the literature on the combined effect of these two commonly occurring environmental pollutants (OTA and endosulfan) in animals or human beings. Keeping the above points in mind, the present study was, therefore, undertaken to determine the genotoxic effects of OTA and endosulfan, alone and in combination, in sexually mature male Wistar rats.

\section{Materials and Methods}

\section{Production and analysis of OTA}

Aspergillus ochraceus NRRL-3174 was originally procured from National Centre for Agriculture Utilization Research (NCAUR-3174) Peoria, Illinois, USA. It was grown on sterilized maize as per the method described by Trenk et al. [24]. The extraction and clean up of the toxin sample was done as per the method of AOAC [25] and the quantitative determination of the toxin was done by using thin layer chromatography (TLC) method and TLC scanner (CAMAG, Switzerland).

*Corresponding author: Shashi Nandar Kumar, Environmental Toxicology Laboratory, National Institute of Pathology (ICMR), Safdarjung Hospital Campus, New Delhi-110 029, India, Tel: +91-9418053235; E-mail: shashinsingh@gmail.com

Received February 19, 2014; Accepted March 28, 2014; Published March 31, 2014

Citation: Kumar SN, Telang AG, Patil RD, Jain AK, Singh KP (2014) Cytogenetic Effects of Combined Ochratoxin A and Endosulfan in Rats. J Environ Anal Toxicol 4: 217. doi: 10.4172/2161-0525.1000217

Copyright: (c) 2014 Kumar SN,, et al. This is an open-access article distributed under the terms of the Creative Commons Attribution License, which permits unrestricted use, distribution, and reproduction in any medium, provided the original author and source are credited. 


\section{Preparation of toxicated feed}

Cultured maize powder containing known amount of OTA was added to basal ration in such proportion that the final concentration of OTA was adjusted to $4 \mathrm{mg} / \mathrm{kg}$ feed. Aliquots were taken from the mixed diet and the toxin was further quantified to ensure the proper mixing of the toxin

\section{Dosing of endosulfan}

Technical grade ( $>99.98 \%$ pure crystalline form) endosulfan, procured from Shri-Ram Chemicals Ltd., India, was dissolved in corn oil (vehicle) and orally intubated to male rats at the rate of $5 \mathrm{mg} / \mathrm{kg}$ body weight, daily for 30 days. The treatment volume was $0.1 \mathrm{ml} / 100$ $\mathrm{gm}$ of body weight. Fresh solution of endosulfan was prepared on each day of treatment. Control animals received an equal volume of corn oil similar to those treated with endosulfan.

\section{Experimental animals and study design}

A total of sixty $(60)$ sexually mature $(180 \pm 20$ grams $)$, male Wistar rats, procured from the Laboratory Animal Resource (LAR) Section of the Indian Veterinary Research Institute, Izatnagar, Bareilly, Uttar Pradesh, India were maintained on standard feed and water available ad libitum. After one week of acclimatization period, the animals were randomly distributed into five groups of 12 rats each and treated for 30 days as follows: Group I animals were fed with a diet containing OTA at the level of $4 \mathrm{mg} / \mathrm{kg}$ feed; Group II animals received endosulfan at the rate of $5 \mathrm{mg} / \mathrm{kg}$ body weight by oral intubation; Group III animals received OTA ( $4 \mathrm{mg} / \mathrm{kg}$ feed) and endosulfan $(5 \mathrm{mg} / \mathrm{kg}$ body weight); Group IV animals were fed with standard mycotoxin free basal diet and served as control; and finally Group V animals were injected intraperitoneally with a single dose of $20 \mathrm{mg} / \mathrm{kg}$ body weight cyclophosphamide and used as positive control. All the experimental procedures and sacrifice of rats were carried out as per the approved guidelines of Institutional Animal Ethics Committee (IAEC) and Committee for the Purpose of Control and Supervision of Experiments on Animals (CPCSEA).

\section{Micronuclei assay}

Isolation of bone marrow cells and preparation of slides for micronuclei assay was carried out on six rats from each group following the methods of Hayashi et al. [26] and Chauhan et al. [27]. Briefly, bone marrow aspirated from both the femurs was added to the Hank's balance salt solution (HBSS, pH 7.2) containing EDTA and BSA. The resulting cell suspension was centrifuged at $1000 \mathrm{rpm}$ for 10 minutes. The cells in the sediment were mixed carefully. A drop of cell suspension was taken and smeared on clean slides, fixed with methanol for 5 minutes and stained with acridine orange for 3 minutes at room temperature. The slides were rinsed thrice in Sorensen's buffer (pH 6.8) for 3 minutes each time, mounted with the same buffer and sealed with Balsam paraffin. Observations were made within a day. The frequency of the micronucleated cells was determined by scoring a minimum of 2000 polychromatic erythrocytes (PCE), while 200 bone marrow erythrocytes were examined to calculate the ratio of PCE to normochromatic erythrocytes (NCE)

\section{Chromosomal aberration assay}

Preparation of chromosomes of bone marrow cells and assessment of chromosomal aberrations was carried out by using the methodology of Malhi and Grover [28] and Chauhan et al. [27]. Briefly, 24 hours prior to the sacrifice, six rats each from all the treated groups were injected intraperitoneally with colchicine $(4 \mathrm{mg} / \mathrm{kg}$ body weight) to arrest cell division at metaphase. Animals were sacrificed by cervical dislocation for preparation of the chromosomes of bone marrow cells. Both femurs were dissected out and the adhering muscle tissue was cleaned off. Bone-marrow cells were collected from both the femurs by flushing in HBSS (pH 7.2) and cell suspension was centrifuged at $1000 \mathrm{rpm}$ for 10 minutes. The pellet was resuspended in hypotonic solution of potassium chloride $(\mathrm{KCl}, 0.56 \% \mathrm{w} / \mathrm{v})$ for 30 minutes and then incubated at $37^{\circ} \mathrm{C}$ to permit osmotic swelling of cells. The cells were centrifuged and the pellets were resuspended in chilled Carnoy's fixative (methanol: glacial acetic acid, 3:1). After 2 hours fixation, the cells were centrifuged, resuspended in a small volume of fixative, dropped onto chilled slides from a height of about 2-2.5 feet, flame-dried, stained with $2 \%$ buffered Giemsa ( $\mathrm{pH}$ 6.8). At least fifty well-spread good metaphase plates of each animal were examined microscopically for scoring different types of aberrations.

\section{Statistical analysis}

Statistical analyses were performed with GraphPad 'InStat' software (San Diago, USA). Data were analysed using one-way analysis of variance (ANOVA) to detect differences among groups and the means were compared by Dunnett's Multiple Comparison test. Results are reported as mean values \pm SEM and differences were considered as significant when $\mathrm{P} \leq 0.01$.

\section{Results and Discussion}

Widespread use of pesticides in agriculture is now a worldwide phenomenon. Awareness about the potential harmful effects of pesticide residues on animal and human health has been growing day by day. Formation of micronuclei (MN) and chromosomal aberrations (CA) are most important cytological end points that are routinely used in genotoxicity evaluation $[29,30]$. Since the exposure of environmental pollutants such as mycotoxins or pesticides to animals and human populations occurs mostly through contaminated diet [31], the oral route, was employed in the present study, which was considered more practicable, simulating the natural route of toxicity due to OTA and endosulfan.

In the present study, OTA or endosulfan, alone or in combination caused significantly $(\mathrm{P} \leq 0.01)$ increased micronuclei $(\mathrm{MN})$ induction and decreased PEC to erythrocyte ratio when compared to those in control (Group IV). In group III rats, the values of $\mathrm{MN}$ induction (4.89 fold) and the decreased PEC to erythrocyte ratio (44.63\%) were higher than the individual treatment groups (Group I, II) and were found to be significant $(\mathrm{P} \leq 0.01)$ as compared to those in the group II rats. However, cyclophosphamide, a reference control (Group V) was significantly most effective in inducing the micronuclei (6.52 fold) and decreasing the PCE to erythrocyte ratio (62.86\%) than those in the individual or combined treatment groups of OTA and endosulfan (Group I, II, III). Induction of MN in bone marrow cells and ratio of PCE to erythrocytes of rats are presented in Table 1.

Chromosomal aberrations, viz., gaps, isochromatid gaps, breaks and fragments were observed in the bone marrow cells, as a model for somatic cells of rats from different treatment groups and are presented in Table 2. A significant $(\mathrm{P} \leq 0.01)$ increase in the percent frequencies of aberrant bone marrow cells of rats was seen in all the treated groups (Group I, II, III) when compared to those in the control (Group IV). In combination group (Group III), the percent frequency of aberrant cells was significantly higher $(11.86 \pm 0.93)$ when compared to those in the individual treatment groups of OTA $(7.05 \pm 1.55)$ and endosulfan $(6.52 \pm 1.02)$. However, the effect induced by the positive reference 


\begin{tabular}{|r|c|c|c|c|}
\hline Parameters & \multicolumn{3}{|c|}{ Experimental groups } \\
\hline MN/2000 PCE & I & II & III & V \\
\hline Change (fold) & $4.67 \pm 0.42^{\mathrm{bc}}$ & $3.83 \pm 0.31^{\mathrm{b}}$ & $6.50 \pm 0.43^{\mathrm{c}}$ & $1.33 \pm 0.211^{\mathrm{a}}$ \\
\hline PCE/200 NCE & $(+) 3.51$ & $(+) 2.88$ & $(+) 4.89$ & 0.00 \\
\hline Change (\%) & $85.33 \pm 7.11^{\mathrm{bc}}$ & $97.33 \pm 5.67^{\mathrm{c}}$ & $67.83 \pm 3.87^{\mathrm{b}}$ & $(+) 6.52$ \\
\hline & $(-) 30.34$ & $(-) 20.55$ & $(-) 44.63$ & $45.5 \pm 4.19^{\mathrm{d}}$ \\
\hline
\end{tabular}

Group-I, Ochratoxin A (4 ppm in feed); Group-II, Endosulfan ( $5 \mathrm{mg} / \mathrm{kg}$ body weight); Group-III, Ochratoxin A+ Endosulfan (4 ppm in feed + $5 \mathrm{mg} / \mathrm{kg}$ body weight); Group-IV, Control; Group-V, Cyclophosphamide $(20 \mathrm{mg} / \mathrm{kg}$ body weight by interperitoneal route); Values are expressed as Mean $\pm S E$ ( $\mathrm{n}=6$ ); Mean bearing at least one common superscript do not vary significantly between groups $(\mathrm{P} \leq 0.01)$; $\mathrm{PCE}=$ Polychromatic Erythrocytes; NCE = Normochromatic Erythrocytes; MN=Micronuclei

Table 1: Mean values of frequency of micronuclei induced by ochratoxin $A$ and/or endosulfan in bone marrow cells of male rats.

\begin{tabular}{|c|c|c|c|c|c|c|c|}
\hline Experimental groups & Cells scored/rat & \multicolumn{3}{|c|}{ Structural chromosomal aberrations } & Total structure aberrations & Frequency of aberrant cells (\%) \\
\hline I & $312 / 6$ & 9 & 3 & 9 & 4 & 25 \\
\hline II & $309 / 6$ & 7 & 4 & 6 & 3 & $7.05 \pm 1.55^{\mathrm{b}}$ \\
\hline III & $304 / 6$ & 13 & 4 & 10 & 7 & $6.52 \pm 1.02^{\mathrm{b}}$ \\
\hline IV & $302 / 6$ & 2 & 0 & 1 & 1 & 34 \\
\hline V & $311 / 6$ & 12 & 11 & 9 & 10 & 4 \\
\hline
\end{tabular}

Group-I, Ochratoxin A (4 ppm in feed); Group-II, Endosulfan (5 mg/kg body weight); Group-III, Ochratoxin A+ Endosulfan (4 ppm in feed + 5 mg/kg body weight); Group-IV, Control; Group- $V$, Cyclophosphamide $(20 \mathrm{mg} / \mathrm{kg}$ body weight by interperitoneal route); Values are expressed as Mean \pm SE ( $\mathrm{n}=6$ ); Values with different superscript letters within columns represent significant statistical differences $(P \leq 0.01)$.

Table 2: Mean values of different chromosomal aberrations induced by ochratoxin $A$ and/ or endosulfan in bone marrow cells of male rats.

compound cyclophosphamide (Group V) was found to be highest $(14.39 \pm 0.96)$.

Genotoxic potential of OTA has been reported by earlier workers [32-34]. Moreover, in mammalian cultured cells, OTA increases the frequency of micronuclei [35], indicating a clastogenic or aneugentic effect. OTA-DNA adduct have also been detected in liver and kidneys [36]. OTA is reported to cause DNA strand break in vitro and in vivo, micronuclei unscheduled DNA synthesis, sister chromatid exchange in vitro and gene mutation in bacterial cell/cell lines [37]. Knasmuller et al. [38] also reported that OTA caused increase in frequency of micronuclei. It is likely that MN formation by OTA is at least partly due to clastogenic effects and might be due to either chromosomal breakage or spindle disruption [39]. Micronuclei are thought to arise from chromosomal breaks (double-stranded DNA breaks) or detached portion that arise during the chromosome breakage or exchange. Chromosomal aberration is also a possible etiologic agent involved in Balkan Endemic Nephropathy and associated with urinary tract tumors [40]. The genotoxicity effects of OTA could be the result of kinetic perturbation of dynamic system [33] or of highly compartmental and heterogeneous cells of the bone marrow [41].

The genotoxic effects of endosulfan mainly includes chromosomal damage, sex-linked recessive mutations and sister chromatid exchange on in vitro or in vivo test system or human population $[42,43]$. Moreover, Lu et al. [44] also found that the alpha- and beta-endosulfan were responsible for increased frequency of micronuclei cell, sister chromatid exchanges and DNA strand breaks at different concentration on human HepG2 cells. Endosulfan can cause chromosomal breakage and aneuploidy in mammalian germ cells [45]. The increased per cent frequencies of chromosomal aberrations and micronuclei have also been reported earlier by Usha Rani et al. [46] and Khan and Sinha [47]. Endosulfan-induced chromosomal aberrations might be due to clastogenesis and mitosis disturbance changes.

It is further suggested that OTA and endosulfan might induce an oxidative stress at cellular level leading to generation of reactive oxygen species, which may play a major role in lowering genetic stability or cytotoxicity and responsible for direct or indirect DNA damage in in vivo or in vitro mammalian systems $[18,48,49]$. Moreover, the mutagenicity of OTA in the target tissue (outer renal medulla) of male rat kidney further rules out oxidative DNA damage and provide new structural evidence for DNA adducts formed by OTA, strengthened its involvement in direct genotoxicity which leads to renal carcinogenesis [3]

\section{Conclusion}

The present study highlighted the cytogenetic effects caused by OTA and endosulfan alone and in combination by oral exposure in male Wistar rats. The oral administration of OTA and endosulfan, with or without combination caused increased frequencies of chromosomal aberration and micronuclei formation in rat bone marrow cells. The frequency was higher in the rats receiving both the toxicants which suggest that OTA and endosulfan treatment cause additive or less than additive effect on genotoxicity in rats.

\section{References}

1. Mally A, Dekant W (2009) Mycotoxins and the kidney: modes of action for renal tumor formation by ochratoxin A in rodents. Mol Nutr Food Res 53: 467-478.

2. Reddy L, Bhoola K (2010) Ochratoxins-food contaminants: impact on human health. Toxins (Basel) 2: 771-779.

3. Pfohl-Leszkowicz A, Manderville RA (2012) An update on direct genotoxicity as a molecular mechanism of ochratoxin a carcinogenicity. Chem Res Toxicol 25: $252-262$

4. O'Brien E, Dietrich DR (2005) Ochratoxin A: the continuing enigma. Crit Rev Toxicol 35: 33-60.

5. Peng $X L, X u$ WT, Wang $Y$, Huang KL, Liang ZH, et al. (2010) Mycotoxin Ochratoxin A-induced cell death and changes in oxidative metabolism of Arabidopsis thaliana. Plant Cell Rep 29: 153-161.

6. Wu Q, Dohnal V, Huang L, KuÄ a K, Wang X, et al. (2011) Metabolic pathways of ochratoxin A. Curr Drug Metab 12: 1-10.

7. Jennings-Gee JE, Tozlovanu M, Manderville R, Miller MS, Pfohl-Leszkowicz A, et al. (2010) Ochratoxin A: In Utero Exposure in Mice Induces Adducts in Testicular DNA. Toxins 2: 1428-1444.

8. Pfohl-Leszkowicz A, Petkova-Bocharova T, Chernozemsky IN, Castegnaro M (2002) Balkan endemic nephropathy and associated urinary tract tumours: a review on aetiological causes and the potential role of mycotoxins. Food Addit Contam 19: 282-302

9. USEPA (2007) United State Environmental Protection Agency. Endosulfan Reaves, E., Washington, DC: Office of Prevention, Pesticides and Toxic Substances.

10. Weber J, Halsall CJ, Muir D, Teixeira C, Small J, et al. (2010) Endosulfan, a 
Citation: Kumar SN, Telang AG, Patil RD, Jain AK, Singh KP (2014) Cytogenetic Effects of Combined Ochratoxin A and Endosulfan in Rats. J Environ Anal Toxicol 4: 217. doi: 10.4172/2161-0525.1000217

global pesticide: a review of its fate in the environment and occurrence in the Arctic. Sci Total Environ 408: 2966-2984.

11. Chopra AK, Sharma MK, Chamoli S (2011) Bioaccumulation of organochlorine pesticides in aquatic system--an overview. Environ Monit Assess 173: 905-916.

12. WHO (2002) The WHO Recommended Classification of Pesticides by Hazard and Guidelines to Classification 2009-2002. Geneva: World Health Organization, International Programme on Chemical Safety/Inter-Organization Programme for Sound Management of Chemicals.

13. IPEN (2008) International Persistent Organic Pesticide Elimination Network.

14. Lubick N (2010) Environment. Endosulfan's exit: U.S. EPA pesticide review leads to a ban. Science 328: 1466.

15. Jayashree R, Vasudevan N (2007) Persistence and distribution of endosulfan under field condition. Environ Monit Assess 131: 475-487.

16. Kumar SN, Telang AG, Singh KP, Jain AK, Afroz M, et al. (2011) Experimentally induced toxicity of ochratoxin $A$ and endosulfan in male wistar rats: a hormonal disorder. J Anim Vet Adv10: 1750-1755.

17. Gupta PK, Gupta RC (1979) Pharmacology, toxicology and degradation of endosulfan A review. Toxicology 13: 115-130.

18. Kannan K, Holcombe RF, Jain SK, Alvarez-Hernandez X, Chervenak R, et al (2000) Evidence for the induction of apoptosis by endosulfan in a human T-cell leukemic line. Mol Cell Biochem 205: 53-66.

19. Zervos IA, Nikolaidis E, Lavrentiadou SN, Tsantarliotou MP, Eleftheriadou EK, et al. (2011) Endosulfan-induced lipid peroxidation in rat brain and its effect on t-PA and PAI-1: ameliorating effect of vitamins C and E. J Toxicol Sci 36 423-433.

20. Uboh FE, Asuquo EN, Eteng MU (2011) Endosulfan-induced hepatotoxicity is route of exposure independent in rats. Toxicol Ind Health 27: 483-488.

21. Chugh SN, Dhawan R, Agrawal N, Mahajan SK (1998) Endosulfan poisoning in Northern India: a report of 18 cases. Int J Clin Pharmacol Ther 36: 474-477.

22. Zahm SH, Weisenburger DD, Saal RC, Vaught JB, Babbitt PA, et al. (1993) The role of agriculture pesticides use in the development of non-Hodgkin's lymphoma in women. Arch Environ Health 48: 35-38.

23. Saiyed H, Dewan A, Bhatnagar V, Shenoy U, Shenoy R, et al. (2003) Effect of endosulfan on male reproductive development. Environ Health Perspect 111: 1958-1962.

24. Trenk HL, Butz ME, Chu FS (1971) Production of ochratoxins in different cereal products by Aspergillus ochraceus. Appl Microbiol 21: 1032-1035.

25. AOAC (1995) Official Method of Analysis. 16th Edn. Association of Officia Analytical Chemists, Washington, DC. USA.

26. Hayashi M, Sofuni T, Ishidate M Jr (1983) An application of Acridine Orange fluorescent staining to the micronucleus test. Mutat Res 120: 241-247.

27. Chauhan LK, Pant N, Gupta SK, Srivastava SP (2000) Induction of chromosome aberrations, micronucleus formation and sperm abnormalities in mouse following carbofuran exposure. Mutat Res 465: 123-129.

28. Malhi PK, Grover IS (1987) Genotoxic effects of some organophosphorus pesticides. II. In vivo chromosomal aberration bioassay in bone marrow cells in rat. Mutat Res 188: 45-51.

29. Agarwal DK, Chauhan LK, Gupta SK, Sundararaman V (1994) Cytogenetic effects of deltamethrin on rat bone marrow. Mutat Res 311: 133-138.

30. Kligerman AD, Doerr CL, Tennant AH, Peng B (2000) Cytogenetic studies of three triazine herbicides. II. In vivo micronucleus studies in mouse bone marrow. Mutat Res 471: 107-112.

31. Anderson SJ (1995) Compositional changes in surface mycoflora during ripening of naturally fermented sausages. J Food Protect 58: 426-429.

32. Creppy EE, Kane A, Dirheimer G, Lafarge-Frayssinet C, Mousset S, et al (1985) Genotoxicity of ochratoxin A in mice: DNA single-strand break evaluation in spleen, liver and kidney. Toxicol Lett 28: 29-35.

33. Bose S, Sinha SP (1994) Modulation of ochratoxin-produced genotoxicity in mice by vitamin C. Food Chem Toxicol 32: 533-537.

34. Kumari D, Sinha SP (1994) Effect of retinol on ochratoxin-produced genotoxicity in mice. Food Chem Toxicol 32: 471-475.
35. Ali R, Mittelstaedt RA, Shaddock JG, Ding W, Bhalli JA, et al. (2011) Comparative analysis of micronuclei and DNA damage induced by Ochratoxin A in two mammalian cell lines. Mutat Res 723: 58-64.

36. Maaroufi K, Pfohl-Leszkowicz A, Achour A, el May M, Grosse Y, et al. (1994) [Ochratoxin A genotoxicity, relation to renal tumors]. Arch Inst Pasteur Tunis 71: $21-31$

37. Follmann W, Hillebrand IE, Creppy EE, Bolt HM (1995) Sister chromatid exchange frequency in cultured isolated porcine urinary bladder epithelial cells (PUBEC) treated with ochratoxin A and alpha. Arch Toxicol 69: 280-286.

38. Knasmuller S, Cavin C, Chakraborty A, Darroudi F, Majer BJ, et al. (2004) Structurally related mycotoxins ochratoxin $A$, ochratoxin $B$, and citrinin differ in their genotoxic activities and in their mode of action in human-derived liver (HepG2) cells: implications for risk assessment. Nutr Cancer 50: 190-197.

39. Pfeiffer E, Gross K, Metzler M (1998) Aneuploidogenic and clastogenic potential of the mycotoxins citrinin and patulin. Carcinogenesis 19: 1313-1318.

40. Castegnaro M1, Canadas D, Vrabcheva T, Petkova-Bocharova T, Chernozemsky IN, et al. (2006) Balkan endemic nephropathy: role of ochratoxins A through biomarkers. Mol Nutr Food Res 50: 519-529.

41. Savage JRK (1990) Mechanism of chromosomal aberrations. Biochem Biophy 279: 402-405.

42. Dulout FN, Pastori MC, Olivero OA, González Cid M, Loria D, et al. (1985) Sister-chromatid exchanges and chromosomal aberrations in a population exposed to pesticides. Mutat Res 143: 237-244.

43. Naqvi SM, Vaishnavi C (1993) Bioaccumulative potential and toxicity of endosulfan insecticide to non-target animals. Comp Biochem Physiol C 105: 347-361.

44. Lu Y, Morimoto K, Takeshita T, Takeuchi T, Saito T (2000) Genotoxic effects of alpha-endosulfan and beta-endosulfan on human HepG2 cells. Environ Health Perspect 108: 559-561.

45. Pandey N, Gundevia F, Prem AS, Ray PK (1990) Studies on the genotoxicity of endosulfan, an organochlorine insecticide, in mammalian germ cells. Mutat Res 242: 1-7.

46. Usha Rani MV, Reddi OS, Reddy PP (1980) Mutagenicity studies involving aldrin, endosulfan, dimethoate, phosphamidon, carbaryl and ceresan. Bull Environ Contam Toxicol 25: 277-282.

47. Khan PK, Sinha SP (1996) Ameliorating effect of vitamin C on murine sperm toxicity induced by three pesticides (endosulfan, phosphamidon and mancozeb). Mutagenesis 11: 33-36.

48. Grosse Y, Chekir-Ghedira L, Huc A, Obrecht-Pflumio S, Dirheimer G, et al. (1997) Retinol, ascorbic acid and alpha-tocopherol prevent DNA adduct formation in mice treated with the mycotoxins ochratoxin $A$ and zearalenone. Cancer Lett 114: 225-229.

49. Hadjeba-Medjdoub K, Tozlovanu M, Pfohl-Leszkowicz A, Frenette C, Paugh RJ, et al. (2012) Structure-activity relationships imply different mechanisms of action for ochratoxin A-mediated cytotoxicity and genotoxicity. Chem Res Toxicol 25: 181-190. 